\title{
Faktor-Faktor yang Mempengaruhi Kinerja Pengawas Koperasi Serba Usaha
}

\author{
Kadek Ardi Gunawan ${ }^{1}$ \\ Fakultas Ekonomi dan Bisnis \\ Universitas Udayana, Indonesia. \\ Email: kdardigunawan@gmail.com
}

\author{
I Dewa Nyoman Badera² \\ Fakultas Ekonomi dan Bisnis \\ Universitas Udayana, Indonesia.
}

\begin{abstract}
ABSTRAK
Pengawas merupakan orang yang ditunjuk dan diberikan tanggungjawab untuk mengontrol kegiatan dalam suatu organisasi. Pengawas koperasi merupakan bagian dari anggota yang memiliki kewajiban untuk mengawasi seluruh operasional yang dilakukan koperasi. Penelitian ini memiliki tujuan untuk memperoleh bukti empiris terkait pengaruh independensi, keahlian profesional, pengalaman kerja, tingkat pendidikan, dan program pelatihan pada kinerja pengawas koperasi serba usaha. Populasi menggunakan seluruh koperasi serba usaha di Kabupaten Klungkung, dengan metode penentuan sampel yaitu non-probability sampling khususnya sampling jenuh yang menggunakan seluruh anggota populasi sebagai sampel sebanyak 87 orang. Penelitian menunjukkan bahwa semua variabel memberikan pengaruh positif dan signifikan pada kinerja pengawas.
\end{abstract}

Kata Kunci : Independensi, Keahlian, Pengalaman, Pendidikan, Pelatihan.

\section{Factors Affecting the Performance of Multipurpose Cooperative Supervisors}

\begin{abstract}
Supervisors are people who are appointed and given the responsibility to control activities within an organization. Cooperative supervisors are part of members who have an obligation to oversee all operations carried out by the cooperative. This study aims to obtain empirical evidence related to the influence of independence, professional expertise, work experience, level of education, and training programs on the performance of all business cooperative supervisors. The population uses all business cooperatives in Klungkung Regency, with the method of determining the sample, which is a non-probability sampling, especially saturated sampling which uses all members of the population as a sample of 87 people. Research shows that all variables have a positive and significant influence on supervisor performance.
\end{abstract}

Keywords: Independency, Expertise, Experience, Education, Trainin.

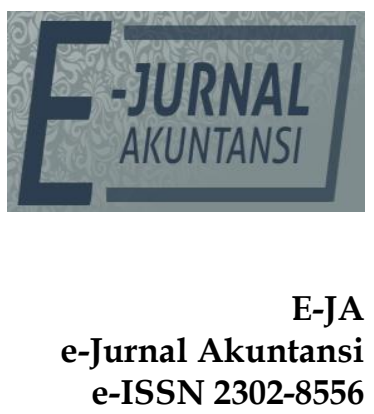

Denpasar, Vol. 28 No. 3

September 2019 Hal. 2001-2018

Artikel masuk: 27 Juni 2019

Tanggal diterima: 02 September 2019 


\section{PENDAHULUAN}

Indonesia mencatat Provinsi Bali sebagai salah satu daerah dengan koperasi yang tergolong berhasil (Prawitasari et al., 2015). Dinas Koperasi Usaha Kecil, Menengah, dan Perdagangan Kabupaten Klungkung mencatat sejak tahun 2015 hingga 2018 terdapat 9 koperasi yang dinyatakan tidak aktif dari sejumlah 38 unit KUD yang ada. Diketahui kondisi ini terjadi karena kurang maksimalnya manajemen koperasi, dan beberapa koperasi yang ternyata tidak melakukan Rapat Anggota Tahunan.

Koperasi pada dasarnya adalah suatu organisasi yang terdiri dari beberapa orang dengan visi dan misi bersama untuk memberikan kesejahteraan pada masing-masing anggota. Koperasi sendiri memiliki peran yang cukup penting dalam perekonomian negara. Koperasi dapat meningkatkan taraf hidup masyarakat karena mampu menyerap tenaga kerja sehingga mengurangi pengangguran. Koperasi juga bermanfaat baik bagi anggotanya karena setiap keuntungan yang diperoleh koperasi sepenuhnya digunakan untuk kesejahteraan para anggota. Pentingnya keberadaan koperasi menyebabkan koperasi memerlukan mekanisme organisasi yang baik dan harus memiliki staff khusus untuk mengawasi kinerjanya.

Koperasi Serba Usaha merupakan koperasi yang meliputi beberapa kegiatan seperti simpan pinjam, waserda, dan lainnya. Sebagai badan yang resmi di mata hukum, seluruh jenis koperasi tak terkecuali Koperasi Serba Usaha (KSU) harus patuh pada undang-undang yang mengatur tentang perkoperasian yaitu UU Nomor 17 Tahun 2012. Semua jenis koperasi sepatutnya memiliki sistem pengawasan dan pengandilan intern yang memadai, terlebih KSU yang bidang usahanya sendiri terdiri atas beberapa kegiatan yang tentunya cukup kompleks dan membutuhkan perhatian khusus. Pengendalian intern yang memadai bertujuan untuk memastikan bahwa koperasi telah dijalankan sesuai dengan peraturan perkoperasian dan semua anggota melaksanakan tugas sesuai porsi masing-masing, sehingga tujuan utama organisasi koperasi dapat dicapai dengan sebaiknya. Dalam mencapai pengendalian intern yang memadai koperasi memerlukan adanya internal auditor yang dapat memastikan bahwa segala bentuk risiko yang terjadi dapat dikelola dengan maksimal.

Auditor internal dalam konteks koperasi dilaksanakan oleh pengawas. Pengawasan koperasi meliputi seluruh kegiatan yang berhubungan dengan pemantauan pelaksanaan dan hasil Rapat Anggota Tahunan (RAT), pemeriksaan tugas masing-masing bagian, mengevaluasi kebijakan yang telah ditetapkan, dan sebagainya yang berhubungan dengan kontrol dan evaluasi serta penilaian keefektivan prosedur dan penyimpangan yang terjadi (Sadhana \& Rasmini, 2014). Keberhasilan mekanisme pengawasan dapat dinilai dari kinerja petugas audit internal. Trisnaningsih, (2007) menyatakan bahwa kinerja auditor memperlihatkan kewajiban pemeriksaan yang telah diselesaikan oleh auditor. Dalam menyelesaikan tugasnya, seorang auditor harus memberikan penilaian secara objektif dan sesuai dengan fakta yang terjadi (Prawitasari, et al., 2015). 
Pengawas berperan dalam mengendalikan jalannya operasional suatu badan usaha. Mengingat pentingnya peran pengawas ini, mengharuskan mereka untuk membekali diri dengan kualitas yang baik. Pengawas dari dalam badan usaha bertanggung jawab penuh terhadap pengendalian intern (Desyanti \& Ratnadi, 2006). Pengawas internal bertugas untuk menemukan kemungkinan kesalahan yang terjadi dan sedinimungkin membenahi kesalahan tersebut, sehingga penyimpangan dapat dicegah dan diminimalisir. Kualitas pengawas internal menunjukkan bahwa mereka memiliki indepensi untuk melaporkan temuan apa adanya, memiliki keahlian dalam bidang pemeriksaan, berpengalaman dalam melakukan tugas sebagai pengawas, pendidikan yang mumpuni sesuai dengan jabatan yang diduduki sebagai pengawas, dan mengikuti berbagai macam program pelatihan untuk menunjang kemampuan yang dimiliki. Indepensi menunjukkan bahwa seseorang memiliki pendirian yang tetap dan tidak mudah untuk menerima pengaruh dari orang lain (Mulyadi, 2002). Independensi bagi seorang pengawas menunjukkan mutu diri yang dimiliki untuk berpegang teguh pada hasil temuan tanpa mengindahkan pendapat orang lain yang bersifat mempengaruhi, dan memperlihatkan integritas diri yang dimilikinya. Integritas dapat diartikan sebagai jati diri dan sifat kejujuran yang dimiliki seseorang terlebih ketika melaksanakan kewajiban sesuai tugasnya. Keahlian dan independensi yang dimiliki auditor dapat menjamin tingkat prediksinya dalam menilai dan mengawasi kegiatan organisasi dibandingkan dengan yang tidak memiliki keahlian dan independensi (Mayangsari \& Sekar, 2003).

Keahlian profesional menunjukkan bahwa orang tersebut telah diakui kemahirannya dalam hal yang dibidangi. Keahlian dapat diperoleh dengan menempuh pendidikan yang sesuai serta mengikuti pelatihan yang terkait. Petugas pengawas yang memiliki keahlian akan memudahnya pekerjaannya karena ia telah terbiasa dan telah benar-benar mengerti apa yang harus dilakukan dalam tugasnya sebagai seorang pengawas. Akmal, (2006) berpendapat bahwa sebagai seorang auditor hal mendasar yang harus dimiliki adalah keahlian dan ketelitian dalam melakukan pemeriksaan.

Pengalaman kerja memberikan pelajaran berbeda setiap harinya. Seorang pengawas yang memiliki banyak pengalaman akan lebih terlatih untuk berhadapan dalam setiap situasi kerja, dan memiliki banyak solusi alternatif ketika dalam situasi tertentu. Pengalaman kerja yang banyak seiring berjalannya waktu akan meningkatkan kemampuan pengawas dalam mengontrol segala kegiatan usaha dan mengkoreksi apabila ditemukan adanya kesalahan. Pengalaman kerja auditor memiliki pengaruh parsial dan signifikan pada keefektivan sistem pengendalian intern (Desyanti \& Ratnadi, 2006).

Tingkat pendidikan menunjukkan bahwa seseorang telah matang dari segi teori yang diperoleh selama proses pendidikan berlangsung. Pendidikan yang cukup memberikan sinyal bahwa seorang pengawas memiliki modal dasar untuk mampu melaksanakan tugasnya dengan baik. Cloyd, (1997) dalam penelitiannya menemukan bahwa tingkat pendidikan seseorang dapat menunjukkan kualitas yang dimiliki. Semakin tinggi pendidikan, auditor memiliki wawasan lebih luas sejalan dengan bidang profesinya, dan memiliki kompetensi yang cukup untuk mempraktekannya dalam kerja nyata. 
Pendidikan dewasa ini menjadi salah persyaratan mutlak dalam promosi seseorang menuju jabatan tertentu. Maka dari itu, pengawas dengan fungsinya yang cukup penting diharapkan memiliki tingkat pendidikan yang memadai pula untuk menunjang profesinya tersebut.

Kualitas kerja pengawas intern didorong dengan program pelatihanpelatihan profesional sebagai respon dari keinginan untuk memiliki sumber daya manusia yang berkualitas (Munandar \& Ashar, 2009). Pelatihan sebagai bentuk pendidikan jangka pendek dengan tujuan meningkatkan keterampilan yang dimiliki, yang biasanya dilakukan dalam bentuk seminar, lokakarya, maupun simposium. Penelitian ini mengkaji ulang hal-hal yang menjadi faktor pendorong kinerja pengawas koperasi sebagai auditor internal, sehingga diharapkan penelitian ini dapat menjadi masukan berbagai pihak khususnya koperasi untuk meningkatkan kinerja koperasi secara umum.

Suatu karakteristik yang dimiliki masing-masing orang yang menduduki jabatan tertentu. Seorang pengawas atau auditor hendaknya memikirkan hal-hal tersebut, karena karateristik semacam itu mempengaruhi kepribadian, sikap, dan aktivitas yang dilakukannya. Kesadaran akan perbedaan yang dimiliki membantu dalam memastikan terjalinnya hubungan yang lebih harmonis. Secara umum, terdapat beberapa tingkah laku yang dimiliki oleh pihak-pihak yang akan diaudit, diantaranya menjadi pribadi yang lebih produktif yaitu pribadi yang sibuk melakukan pekerjaan-pekerjaan yang lebih bermakna, memiliki dedikasi yang tinggi terhadap pekerjaan yang dianggap penting, memiliki kesadaran untuk membantu individu lain, independensi, adil, jujur, lebih suka dipuji daripada diberikan kritik, berusaha mendapatkan kepuasan diri sendiri, memiliki nilai tawar untuk memperoleh imbalan atas usaha yang dilakukan, memiliki rasa iba atas bencana yang menimpa orang lain, memaksimal keuntungan diri sendiri. Dalam keadaan yang di dalamnya terdapat hubungan interpersonal seperti yang biasa kita lihat pada audit internal, merupakan hal yang wajib dan penting untuk menyadari dan berpedoman pada keseimbangan dan memandang diri sendiri sebagaimana orang lain memandangnya. Elemen utama dari kondisi semacam ini adalah memiliki kesadaran pada kekuatan dan kelemahan yang dimiliki orang lain, rasa memiliki produktivitas dan kepuasan kelompok, keinginan untuk memberikan pelayanan terhadap kebutuhan orang lain, dan perasaan terpadu atas kepercayaan bahwa seseorang berpartisipasi dalam lingkungan secara etis (Lubis, 2017).

Teori perilaku individu menjadi bahasan yang penting dan menarik karena memberikan penjelasan terkait fenomena sosial seperti perilaku pasar. Salah satunya adalah keengganan terhadap kerugian yang telah dijelaskan dalam berbagai macam percobaan sebagai bias dari status quo atau ketergantungan referensi (Górecka \& Strojek-filus, 2017). Secara tradisional, orang telah diharapkan dan diasumsikan berperilaku sedemikian rupa untuk memaksimalkan utilitas, akibatnya mengarah pada harapan individu dalam lingkaran keuangan menjadi homo economicus yang bertentangan dengan ciri khas homo sapiens (Bali, 2012). Sebagai sumber daya, karyawan adalah salah satu aset organisasi yang paling berharga. Orang-orang menciptakan organisasi, membimbing dan mengarahkan jalannya, dan menghidupkan serta merevitalisasi. Orang membuat keputusan, memecahkan masalah, dan 
menjawab pertanyaannya. Ketika manajer semakin menyadari nilai kontribusi potensial oleh karyawan mereka, akan semakin penting bagi manajer dan karyawan untuk memahami kompleksitas perilaku masing-masing individu dalam organisasi. Perilaku individu dijelaskan oleh serangkaian tindakan yang dilakukan dalam lingkungan tertentu. Konsekuensinya mungkin positif, seperti hadiah, insentif, bala bantuan, atau yang negatif seperti sanksi, hukuman atau bala bantuan negatif lainnya. Oleh karena itu, alternatif perilaku dimodelkan sesuai dengan hasil keputusan yang awalnya dibuat (Codreanu, 2010).

Koperasi memiliki beberapa anggota dengan tanggungjawab masingmasing, seperti rapat anggota, pengurus, dan pengawas. Kekuasaan koperasi tertinggi berada di tangan rapat anggota. Rapat anggota mendelegasikan tugas dan kewajiban para perngurus dan pengawas, sebaliknya pengurus dan pengawas bertanggung jawab dalam melaporkan kegiatan usaha kepada rapat anggota. Koperasi terdiri atas orang-orang yang memiliki kesamaan tujuan untuk memperoleh kesejahteraan lahiriah, yang bergabung tanpa adanya pengaruh pihak lain (Hendrojogi, 2010). Undang-undang Nomor 25 Tahun 1992 menyebutkan bahwa koperasi berdasar pada asas kekeluargaan antar anggotanya. Tujuan koperasi disebutkan untuk mencapai kesejahteraan anggota dan masyarakat pada umumnya, bersama membangun perekonomian masyarakat yang adil, makmur dilandasi oleh Pancasila dan UUD 1945. Koperasi pada umumnya terdiri atas orang-orang dengan perekonomian rendah yang memiliki visi dan misi untuk mencukupi kebutuhan. Sesuai dengan namanya, Koperasi Serba Usaha (KSU) bergerak di bidang berbagai macam usaha yang lebih kompleks dibandingkan koperasi lain yang hanya fokus pada satu bidang. Kompleksitas kegiatan usahanya membuat KSU memerlukan mekanisme pengawasan yang maksimal dan terjamin, untuk memastikan semuanya berjalan sesuai dengan hasil keputusan rapat anggota.

Pengawas koperasi merupakan anggota koperasi yang telah dipilih untuk melakukan fungsi pengawasan terhadap operasional koperasi (Arifin \& Halomon, 2001). Pengawas koperasi bertugas dalam memeriksa catatan, pembukuan tahunan koperasi, mengevaluasi pelaksanaan anggaran, dan mengawasi kinerja pengurus lainnya. Hasil pemeriksaan pengawas kemudian disampaikan kepada para anggota untuk dikaji lebih lanjut. Diharapkan dengan adanya monitor dari tim pengawas koperasi maka jalannya koperasi akan lebih teratur dan sesuai kesepakatan dalam rapat anggota.

ASOBAC (a statement off basic auditing concept) menyebutkan pengertian audit sebagai suatu proses untuk mengumpulkan dan memeriksa bukti-bukti dari peristiwa ekonomi yang terjadi untuk memastikan kesesuaiannya dengan aturan yang telah ditetapkan yang kemudian melaporkan hasil tersebut kepada pihak manajemen (Halim, 2011). Audit merupakan proses evaluasi yang dilakukan oleh pihak independen terhadap laporan keuangan dan bukti-bukti transaksi keuangan secara objektif untuk memberikan pendapat terkait kesesuainnay dengan kriteria (Sukrisno, 2004). Internal audit memiliki kewajiban untuk memberikan saran dan pendapat independen untuk memberikan koreksi pada organisasi (Sawyer's, 2005). Internal audit melakukan tugas pengawasan untuk menentukan beberapa hal, (1) keandalan informasi; (2) pengurangan risiko; (3) kepatuhan terhadap peraturan yang berlaku; (4) syarat 
operasi bisnis telah dijalankan; (5) penggunaan sumber daya secara efektif; dan (6) tercapainya tujuan organisasi. Internal auditor menjalankan fungsi pengawas independen yang memberikan pendapatnya setelah melakukan pemeriksaan kepada manajemen terkait ketepatan operasi perusahaan dengan aturan dan ketepatan penggunaan sumber daya (Davies, 2001).

Kinerja didefinisikan sebagai hasil dari pekerjaan yang telah dilakukan oleh seseorang sesuai dengan porsi tanggungjawabnya (Mangkunegara, 2005). Kinerja karyawan merupakan hasil kerja yang telah diselesaikan oleh karyawan dalam suatu organisasi untuk mencapai tujuan (Hariandja, 2007). Kinerja karyawan yang baik akan meningkatkan produktivitas usaha (Hakim, 2015). Kinerja terbagi menjadi dua jenis yakni kinerja individu dan kinerja organisasi. Kinerja individu memfokuskan perhatian pada pencapaian kerja masing-masing karyawan sesuai yang telah ditetapkan manajemen perusahaan (Engko, 2008). Peningkatan kinerja dapat dilihat dari meningkatnya jumlah dan kualitas dari pekerjaan yang dilakukan.

Independensi merupakan sikap untuk tidak dipengaruhi dan tidak berkaitan dengan pemeriksaan (Hery, 2010). Seorang internal auditor hendaknya memiliki kemandirian dalam dirinya untuk menghindari pendapat bias yang mungkin diberikan. Independensi merupakan modal awal bagi seorang auditor dan sangat penting untuk dimiliki (Antle, 1984). Zhang, et al., (2007) menyatakan bahwa independensi auditor berkaitan erat dengan pelaporan masalah pengendalian internal. Institut akuntansi di Amerika yaitu Americsn Institute of Certified Public Accounting (AICPA) menyatakan independensi merupakan sikap yang objektif dan menunjukkan adanya integritas dalam diri (Mayangsari \& Sekar, 2003). Integritas menunjukkan sikap jujur dan melaporkan temuan sesuai dengan fakta yang ditemukan. Pengawas seharusnya menjunjung intergritas diri, karena hal tersebut menunjukkan kualitas profesional yang dimilikinya. Integritas pengawas memperlihatkan bahwa mereka melakukan pengawasan dengan baik, jujur, dan tidak memihak salah satu pihak. Hal ini sangat penting untuk menentukan keandalan informasi keuangan dan keputusan pendapat pengawas mengenai jalanya operasi perusahaan.

Keahlian profesional terdiri atas tiga kategori, pertama, memiliki pengalaman sesuai bidangnya, kedua, profesional berarti memiliki moral, dan etika profesi, dan ketiga, profesional sama halnya dengan moral yang ada pada diri mereka (Fujianti, 2012). Ahli berarti seseorang yang memiliki kompetensi dan kemampuan mumpuni dalam bidangnya. Pelaksanaan audit internal membutuhkan keahlian dan kemampuan yang cukup dalam mengidentifikasi aktivitas ekonomi (Boyton \& Kell, 2003). Profesional mengandung arti kondisi kematangan baik fisik maupun mental yang diperoleh melalui pendidikan dan pelatihan yang cukup lama untuk meningkatkan teknik dan kualitan yang dimiliki dengan tujuan untuk mencapai keunggulan diantara profesional yang lainnya. Murtanto \& Gudono, (1999) mengemukakan komponen keahlian diantaranya, pengetahuan terkaitan prosedur, serta pengalaman, ciri psikologis seperti komunikasi, kepercayaan, kreativitas, kemampuan berpikir, strategi dalam mengambil keputusan, dan kemampuan menganalisis tugas.

Pengalaman sebagai lamanya waktu yang ditempuh seseorang dalam menjalankan peran sesuai bidang keahliannya. Pengalaman kerja merupakan 
salah satu hal yang dapat digunakan untuk mengidentifikasi kinerja seorang auditor (Bonner, 1990). Pengalaman menunjukkan auditor telah semakin matang dan semakin teruji dalam menyelesaikan berbagai macam situasi pemeriksaan yang ditemui. Kemampuan yang meningkat karena mengikuti pelatihan secara khusus sama halnya dengan ketika memiliki banyak pengalaman untuk menjadi seorang profesional (Herliansyah \& Buana, 2015). Seseorang yang memiliki banyak pengalaman sesuai keahliannya akan memiliki lebih banyak ingatan dalam pikirannya terkait bidang yang digeluti tersebut.

Pendidikan sebagai salah satu upaya untuk meningkatkan kualitas sumber daya manusia yang dimiliki, menambah wawasan dan pengetahuan dalam bentuk teori maupun keterampilan dengan tujuan untuk dapat menghadapi berbagai permasalahan (Dewi, 2011). Dalam menjalankan tugas sebagai seorang pengawas maupun audit, tingkat pendidikan juga tak kalah penting untuk menambah kualitas dan kemampuan dalam memeriksa. Pendidikan memberikan pengetahuan awal terkait teori-teori yang terkandung dalam proses pengauditan, serta pemahaman mengenai standar resmi yang diberlakukan lembaga terkait. Yasa \& Saputra, (2013) dalam penelitiannya menemukan bahwa tingkat pendidikan yang tinggi mampu membuat auditor melaksanakan tugas auditingnya secara efektif dan efisien.

Pelatihan merupakan salah satu cara efektif untuk meningkatkan kemampuan seorang karyawan. Pelatihan yang teratur terkait berbagai macam perkembangan dalam dunia audit dapat menambah wawasan karyawan dan meningkat profesionalismenya. Standar umum auditing menyatakan bahwa auditor harus memiliki kecakapan profesional untuk dapat melaksanakan tugasnya. Kecakapan ini dapat ditingkatkan melalui pelatihan profesional (Rai, 2008). Tujuan utama pelatihan sesungguhnya adalah untuk menambah nilai dan kualitas para karyawan, hal ini menyebabkan banyak organisasi yang menjadwal pelatihan secara rutin (Elnaga \& Imran, 2013).

Independensi menunjukkan bagaimana seorang pengawas mampu melakukan pekerjaannya sesuai standar dan tidak mudah menerima pengaruh pihak lain, serta melaporkan sesuai yang ditemukan dalam pemeriksaan. Sikap semacam ini penting untuk menjamin sistem pengawasan dialkukan secara tepat dan efektif (Hirth, 2016). Independensi memberikan pengaruh pada kinerja pengawas sesuai penelitian yang dilakukan oleh Junitayanti, (2011). Sejalan dengan penelitian Allen, (2005) bahwa semakin baik sikap independensi yang dimiliki auditor maka semakin baik pula kinerjanya. Hal tersebut menjadi dasar penulis dalam merumuskan hipotesis pertama, berikut.

$\mathrm{H}_{1}$ : Independensi berpengaruh pada kinerja pengawas.

Kecakapan profesional mutlak dimiliki auditor dalam menjalankan penugasan audit karena telah diatur dalam SPAP SA 04. Kinerja dipengaruhi oleh keahlian profesional (Dianawati \& Ramantha, 2013). Profesional menunjukkan bahwa seseorang memiliki kemampuan, keterampilan, dan etika profesi yang menunjang pekerjaannya. Auditor yang profesional mampu menyelesaikan pekerjaan tepat waktu, penuh ketelitian, dan mengutamakan etika profesi. Kalbers \& Fogarty, (1995) memperoleh hasil penelitian adanya pengaruh positif antara keahlian profesional dengan kinerja. Berdasarkan hal tersebut, rumusan masalah kedua adalah. 
$\mathrm{H}_{2}$ : Keahlian professional berpengaruh pada kinerja pengawas.

Sama halnya dengan independensi dan keahlian profesional, pengalaman juga merupakan faktor penting yang setidaknya harus dimiliki auditor. Pengalaman yang cukup akan membantu auditor dalam menghadapi berbagai macam situasi dan kemungkinan-kemungkinan yang terjadi selama proses pengawasan dan pemeriksaan. Semakin banyak pengalaman auditor maka akan semakin baik pula kualitas dari proses audit dan pendapat yang dikemukakan terkait pemeriksaan (Putra \& Wisadha, 2013). Dewi, (2011) dalam penelitiannya memperoleh hasil bahwa pengalaman dan kinerja berpengaruh positif. Hipotesis ketiga dalam penelitian ini adalah.

$\mathrm{H}_{3}$ : Pengalaman kerja berpengaruh pada kinerja pengawas.

Pendidikan bertujuan dalam meningkatkan sumber daya manusia dalam hal kemampuan dan keterampilan untuk mengantisipasi perubahan yang kemungkinan akan terjadi (Syafaruddin, 2001). Tingkat pendidikan telah terbukti dalam meningkatkan kualitas dari hasil audit (Rahma, 2012). Sejalan dengan penelitian Murtini, (2017) bahwa pendidikan memberi pengaruh positif dan signifikan pada kinerja dari pengawas. Pendidikan merupakan modal dalam mencapai profesionalisme kerja bagi auditor. Berdasarkan hal tersebut hipotesis keempat adalah sebagai berikut.

$\mathrm{H}_{4}$ : Tingkat pendidikan berpengaruh pada kinerja pengawas.

Pelatihan sama halnya dengan pendidikan juga merupakan cara untuk mencapai profesionalisme kerja (Salusu, 2008). Pelatihan memiliki berbagai macam bentuk seperti seminar, on the job training, simposium, dan bentuk lainnya. Pelatihan menambah kemampuan auditor untuk bersosialisasi dan mengetahui isu-isu baru yang berkaitan dengan profesinya. Pelatihan yang dilakukan mampu meningkatkan pengendalian internal. Berdasarkan hasil penelitisn tersebut, maka dapat diajukan hipotesis sebagai berikut.

$\mathrm{H}_{5}$ : Program Pelatihan Berpengaruh pada Kinerja Pengawas.

\section{METODE PENELITIAN}

Peneliti menggunakan Koperasi Serba Usaha di Kabupaten Klungkung sebagai lokasi penelitian. KSU di Kabupaten Klungkung berjumlah 29 unit dan seluruhnya merupakan populasi dalam penelitian ini. Masing-masing koperasi memiliki 3 orang pengawas, sehingga total keseluruhan populasi adalah 87 orang. Keseluruhan populasi digunakan sebagai sampel karena peneliti menggunakan sampling jenuh.

Penelitian ini bertujuan untuk memberikan kajian mengenai bagaimana faktor-faktor yang telah disebutkan mempengaruhi kinerja karyawan pada Koperasi Serba Usaha. Berikut digambarkan desain penelitian pada gambar 1. 




Sumber: Data Penelitian, 2018

Data dikumpulkan dengan metode kuesioner dengan skala likert 5, yakni Sangat Setujut, Setuju, Netral, Tidak Setuju, dan Sangat Tidak Setuju. Teknik analisis data menggunakan regresi linear berganda, dengan rumus seperti yang ditunjukkan berikut.

$Y=\alpha+\beta_{1} X_{1}+\beta_{2} X_{2}+\beta_{3} X_{3}+\beta_{4} X_{4}+\beta_{5} X_{5}+e$

Keterangan:

$\begin{array}{ll}\mathrm{Y} & =\text { Kinerja } \\ \mathrm{X}_{1} & =\text { Independensi } \\ \mathrm{X}_{2} & =\text { Keahlian Profesional } \\ \mathrm{X}_{3} & =\text { Pengalaman Kerja } \\ \mathrm{X}_{4} & =\text { Tingkat Pendidikan } \\ \mathrm{X}_{5} & =\text { Program Pelatihan } \\ \beta_{1} & =\text { Koefesien Independensi } \\ \beta_{2} & =\text { Koefesien Keahlian Profesional } \\ \beta_{3} & =\text { Koefesien Pengalaman Kerja } \\ \beta_{4} & =\text { Koefesien Tingkat Pendidikan }\end{array}$




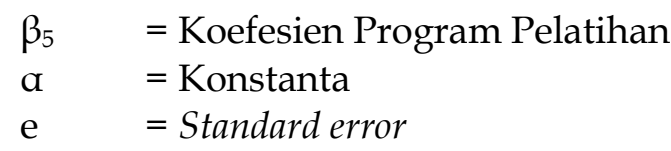

\section{HASIL DAN PEMBAHASAN}

Penelitian berlokasi di Kabupaten Klungkung mengingat terdapat koperasi yang dikatakan sakit dan tidak melakukan Rapat Anggota Tahunan. Kuesioner sebanyak 87 eksemplar disebarkan kepada para pengawas di masing-masing koperasi dengan rincian sebagai berikut pada tabel 1.

\section{Tabel 1. Data Kuesioner}

\begin{tabular}{lc}
\multicolumn{1}{c}{ Keterangan } & Jumlah \\
\hline Total kuesioner yang disebar & 87 \\
Kuesioner yang tidak kembali & 0 \\
Kuesioner yang dikembalikan & 87 \\
Kuesioner yang tidak dapat digunakan & 0 \\
Kuesioner yang digunakan dalam anlisis & 87 \\
Tingkat pengembalian : & $100 \%$ \\
Kuesioner yang dikembalikan X 100\% & \\
\hline Kuesiner yang disebar & $100 \%$ \\
Tingkan pengembalian yang digunakan : & \\
Kuesioner yang digunakan X 100\% & \\
Kuesioner yang disebar &
\end{tabular}

Kuesioner yang disebarkan sejumlah 87 kuesioner, dan keseluruhannya digunakan dalam penelitian. Analisis statistik deskriptif memberikan gambaran informasi yang dilihat dari beberapa hal, seperti rata-rata, nilai maksimum dan minimum, serta standar deviasi dari data penelitian yang bisa dilihat pada tabel 2.

Tabel 2. Hasil Statistik Deskriptif

\begin{tabular}{lccccc}
\hline \multicolumn{1}{c}{ Variabel } & N & Min. & Max. & Mean & $\begin{array}{c}\text { Std. } \\
\text { Devisiasi }\end{array}$ \\
\hline Independensi (X1) & 87 & 22 & 45 & 33,01 & 6.744 \\
Keahlian professional (X2) & 87 & 14 & 35 & 24,44 & 4.810 \\
Pengalaman kerja (X3) & 87 & 16 & 30 & 21,92 & 3.942 \\
Tingkat Pendidikan (X4) & 87 & 13 & 30 & 21,80 & 3.5 .79 \\
Program Pelatihan (X5) & 87 & 11 & 25 & 18,14 & 3.345 \\
Kinerja (Y) & 87 & 32 & 64 & 45,92 & 9.158 \\
\hline
\end{tabular}

Sumber: Data Penelitian, 2019

Variabel Independensi $\left(X_{1}\right)$ memiliki rata-rata sebesar 33,01 yang menunjukkan bahwa karyawan KSU memiliki independensi yang terbilang tinggi. Variabel keahlian profesional $\left(\mathrm{X}_{2}\right)$ nilai rata-rata 24,44 mendekati nilai maksimum sebesar 35, berarti bahwa karyawan KSU memiliki keahlian profesional yang tinggi. Variabel pengalaman kerja $\left(\mathrm{X}_{3}\right)$ mempunyai rata-rata sebesar 21,92 berarti karyawan KSU memiliki pengalaman kerja yang cukup banyak. Variabel tingkat pendidikan $\left(\mathrm{X}_{4}\right)$ rata-ratanya sebesar 21,80 mendekati nilai maksimum 30, menunjukkan bahwa karyawan KSU memiliki tingkat pendidikan yang memadai untuk menjalankan tugasnya. Variabel pelatihan $\left(\mathrm{X}_{5}\right)$ nilai rata-ratanya sebesar 18,14 mendekati nilai maksimum 25, sehingga 
disimpulkan bahwa karyawan KSU telah menerima banyak program pelatihan. Variabel kinerja (Y) mempunyai rata-rata 45,92 memperlihatkan bahwa karyawan KSU berkinerja dengan baik.

Suatu instrument dikatakan valid jika nilai Corrected Item-Total correlation lebih besar dari 0,30. Validitas digunakan untuk mengetahui kelaayakan item pertanyaan untuk digunakan dalam mengukur hasil. Hasil validitas dapat dilihat pada tabel 3 sebagai berikut.

Tabel 3. Hasil uji validasi

\begin{tabular}{|c|c|c|c|c|}
\hline No & Variabel & Kode Intrumen & Koefesien korelasi & Keterangan \\
\hline \multirow[t]{9}{*}{1} & \multirow{9}{*}{$\begin{array}{l}\text { Independensi } \\
\left(\mathrm{X}_{1}\right)\end{array}$} & $\mathrm{X}_{1.1}$ & 0,836 & Valid \\
\hline & & $X_{1} .2$ & 0,818 & Valid \\
\hline & & $X_{1.3}$ & 0,900 & Valid \\
\hline & & $X_{1.4}$ & 0,845 & Valid \\
\hline & & $X_{1.5}$ & 0,767 & Valid \\
\hline & & $X_{1} .6$ & 0,868 & Valid \\
\hline & & $X_{1.7}$ & 0,646 & Valid \\
\hline & & $\mathrm{X}_{1} .8$ & 0,854 & Valid \\
\hline & & $X_{1} .9$ & 0,731 & Valid \\
\hline \multirow[t]{7}{*}{2} & \multirow{7}{*}{ Keahlian Profesional $\left(\mathrm{X}_{2}\right)$} & $X_{2.1}$ & 0,765 & Valid \\
\hline & & $X_{2} .2$ & 0,763 & Valid \\
\hline & & $X_{2.3}$ & 0,823 & Valid \\
\hline & & $X_{2.4}$ & 0,757 & Valid \\
\hline & & $\mathrm{X}_{2.5}$ & 0,737 & Valid \\
\hline & & $X_{2} .6$ & 0,820 & Valid \\
\hline & & $X_{2.7}$ & 0,778 & Valid \\
\hline \multirow[t]{6}{*}{3} & \multirow{6}{*}{$\begin{array}{l}\text { Pengalaman Kerja } \\
\left(X_{3}\right)\end{array}$} & $X_{3.1}$ & 0,811 & Valid \\
\hline & & $X_{3.2}$ & 0,833 & Valid \\
\hline & & $X_{3.3}$ & 0,849 & Valid \\
\hline & & $\mathrm{X}_{3.4}$ & 0,746 & Valid \\
\hline & & $X_{3} .5$ & 0,792 & Valid \\
\hline & & $X_{3} .6$ & 0,835 & Valid \\
\hline \multirow[t]{6}{*}{4} & \multirow{6}{*}{$\begin{array}{l}\text { Tingkat Pendidikan } \\
\left(\mathrm{X}_{4}\right)\end{array}$} & $X_{4} \cdot 1$ & 0,644 & Valid \\
\hline & & $X_{4.2}$ & 0,636 & Valid \\
\hline & & $X_{4} .3$ & 0,788 & Valid \\
\hline & & $\mathrm{X}_{4.4}$ & 0,662 & Valid \\
\hline & & $X_{4} .5$ & 0,811 & Valid \\
\hline & & $X_{4.6}$ & 0,743 & Valid \\
\hline \multirow[t]{5}{*}{5} & \multirow{5}{*}{$\begin{array}{l}\text { Program Pelatihan } \\
\left(X_{5}\right)\end{array}$} & $X_{5}$ & 0,804 & Valid \\
\hline & & $X_{5}$ & 0,788 & Valid \\
\hline & & $X_{5}$ & 0,787 & Valid \\
\hline & & $\mathrm{X}_{5}$ & 0,841 & Valid \\
\hline & & $\mathrm{X}_{5}$ & 0,668 & Valid \\
\hline
\end{tabular}

Bersambung ... 
Lanjutan Tabel 3.

\begin{tabular}{llll}
\hline 6 Kinerja & Y.1 & 0,776 & Valid \\
& Y.2 & 0,823 & Valid \\
& Y.3 & 0,759 & Valid \\
& Y.4 & 0,678 & Valid \\
& Y.5 & 0,655 & Valid \\
& Y.6 & 0,816 & Valid \\
& Y.7 & 0,763 & Valid \\
& Y.8 & 0,854 & Valid \\
& Y.9 & 0,780 & Valid \\
& Y.10 & 0,861 & Valid \\
& Y.11 & 0,638 & Valid \\
& Y.12 & 0,816 & Valid \\
& Y.13 & 0,665 & Valid \\
\hline
\end{tabular}

Sumber: Data Penelitian, 2019

Berdasarkan tabel 3 dapat disimpulkan bawah instrumen penelitian yang terdiri dari item-item pernyataan independensi $\left(X_{1}\right)$, Keahlian professional $\left(X_{2}\right)$, Pengalaman kerja $\left(X_{3}\right)$, Tingkat pendidikan $\left(X_{4}\right)$, program pelatihan $\left(X_{5}\right)$ dan Kinerja (Y) mempunyai nilai koefesien korelasi yang lebih besar dari 0,3 seluruh indikator pernyataan tersebut telah memenuhi syarat validitas data.

Uji reliabilitas digunakan untuk menentukan apakah item pertanyaan memiliki hasil yang konsisten apabila digunakan dalam berberapa kali penelitian secara berulang. Uji reliabilitas terpenuhi apabila nilai cronbach's alpha $>0,60$ seperti yang ditunjukkan pada tabel 4 berikut.

Tabel 4. Hasil Uji Reliabilitas

\begin{tabular}{lcc}
\hline \multicolumn{1}{c}{ Variabel } & Cronbach's Alpha & Keterangan \\
\hline Independensi (X1) & 0,786 & Reliabel \\
Keahlian professional (X2) & 0,789 & Reliabel \\
Pengalaman kerja (X3) & 0,801 & Reliabel \\
Tingkat Pendidikan (X4) & 0,780 & Reliabel \\
Program Pelatihan (X5) & 0,801 & Reliabel \\
Kinerja (Y) & 0,722 & Reliabel \\
\hline
\end{tabular}

Sumber: Data Penelitian, 2019

Sebelum elakukan analisis regresi linear berganda, terlebih dahulu data penelitian harus lolos dalam semua uji asumsi klasik seperti uji normalitas, uji multikoliniearitas, dan uji heteroskedastisitas. Uji normalitas bertujuan untuk mengetahui normal atau tidaknya distribusi variabel residual. Penelitian layak digunakan apabila variabel residual berdistribusi normal, yang ditunjukkan dengan nilai Asymp. Sig (2-tailed)>a. $(0,05)$, seperti tabel 5 berikut ini.

Tabel 5. Hasil Uji Normalitas

\begin{tabular}{lr}
\hline \multicolumn{1}{c}{ Klomogorov-Smirnov Z } & Unstandardized Residual \\
\hline $\mathrm{N}$ & 87 \\
Asymp.Sig.(2-tailed) & 0,76 \\
\hline Sumber: Data Penelitian, 2019
\end{tabular}

Hasil uji normalitas dengan model regresi menunjukkan bahwa nilai residual berdisitribuasi normal sehingga dikatakan layak untuk uji. 
Uji multikoliniearitas untuk menguji ada tidaknya multikoliniearitas dalam penelitian, dimana model yang baik adalah yang tidak mengandung multikolinearitas. Hasil uji tersebut dapat dilihat pada tabel 6 berikut.

Table 6. Hasil Uji Multikolinearitas

\begin{tabular}{lcc}
\hline $\begin{array}{l}\text { Hasil Uji Multikolinearitas } \\
\text { Variabel }\end{array}$ & Tolerance & VIF \\
\hline Independensi $\left(X_{1}\right)$ & 0,417 & 2.396 \\
Keahlian profesinal $\left(X_{2}\right)$ & 0,349 & 2.867 \\
Pengalaman kerja $\left(X_{3}\right)$ & 0,312 & 3.210 \\
Tingkat pendidikan $\left(X_{4}\right)$ & 0,204 & 4.901 \\
Program pelatihan $\left(X_{5}\right)$ & 0,295 & 3.386 \\
\hline
\end{tabular}

Sumber: Data Penelitian, 2019

Dilihat dari Tabel 6 diatas dapat ditarik kesimpulan bahwa nilai tolerance pada masing-masing variabel lebih besar dari 10 persen $(0,1)$, demikian pula dengan nilai VIF dari masing-masing variabel yang lebih kecil dari 10. Hal ini berarti model regresi bebas dari masalah multikolinearitas.

Uji heteroskedastisitas untuk menentuk ada tidaknya kesamaan varian antar variabel bebas yang dilakukan dengan uji glejser, dimana persyaratannya adalah nilai signifikansinya lebih besar dari $a=0,05$, maka tidak terjadi gejala heteroskedastisitas.

\section{Tabel 7. Hasil Uji Heteroskedastisitas}

\begin{tabular}{lcc}
\hline \multicolumn{1}{c}{ Varibael } & Sig. & Keterangan \\
\hline Independensi $\left(\mathrm{X}_{1}\right)$ & 0,468 & Bebas heteroskedastisitas \\
Keahlian profesinal $\left(\mathrm{X}_{2}\right)$ & 0,422 & Bebas heteroskedastisitas \\
Pengalaman kerja $\left(\mathrm{X}_{3}\right)$ & 0,719 & Bebas heteroskedastisitas \\
Tingkat pendidikan $\left(\mathrm{X}_{4}\right)$ & 0,369 & Bebas heteroskedastisitas \\
Program pelatihan $\left(\mathrm{X}_{5}\right)$ & 0884 & Bebas heteroskedastisitas \\
\hline
\end{tabular}

Sumber: Data Penelitian, 2019

Berdasarkan tabel 7 diketahui nilai signifikansi masing-masing variabel bebas lebih dari 0,05 sehingga dapat disimpulkan bahwa model regresi dalam penelitian ini bebas dari gejala heteroskedastisitas.

Analisis linier berganda digunakan untuk memecahkan rumusan masalah yang ada, yaitu untuk melihat pengaruh antara dua variabel atau lebih. Hasil analisis linier berganda disajikan pada tabel 8 .

Tabel 8. Hasil Analisis Regresi Linier Berganda

\begin{tabular}{lccrrr}
\hline \multicolumn{1}{c}{ Variabel } & $\begin{array}{c}\text { Unstandardized } \\
\text { Beta }\end{array}$ & $\begin{array}{c}\text { Std. } \\
\text { Error }\end{array}$ & $\begin{array}{c}\text { Standarized } \\
\text { Beta }\end{array}$ & $\begin{array}{c}\mathrm{T} \\
\text { hitung }\end{array}$ & Sig. uji t \\
\hline (Constant) & 6.480 & 2.356 & & 2.750 & 0,07 \\
Independensi $\left(\mathrm{X}_{1}\right)$ & 0,487 & 0,085 & 0,359 & 5.735 & 0,000 \\
Keahlian profesinal $\left(\mathrm{X}_{2}\right)$ & 0,321 & 0,130 & 0,169 & 2.467 & 0,016 \\
Pengalaman kerja $\left(\mathrm{X}_{3}\right)$ & 0,397 & 0,168 & 0,171 & 2,362 & 0,021 \\
Tingkat pendidikan $\left(\mathrm{X}_{4}\right)$ & 0,533 & 0,229 & 0,208 & 2,330 & 0,022 \\
Program pelatihan $\left(\mathrm{X}_{5}\right)$ & 0,449 & 0,203 & 0,164 & 2.205 & 0,030 \\
Adjusted R & & & & & 0,860 \\
$\mathrm{~F}$ & & & & & 106,376 \\
Sig. F & & & & & \\
\hline Sumber: Data Penelitian & & & & &
\end{tabular}

Dari tabel 8 dapat ditentukan persamaan regresi sebagai berikut.

$$
\mathrm{Y}=6.480+0,487+0,321+0,397+0,533+0,449+\mathrm{e}
$$


Nilai konstanta (a) 6.480 memiliki arti jika variabel independensi $\left(\mathrm{X}_{1}\right)$, keahlian professional $\left(X_{2}\right)$, pengalaman kerja $\left(X_{3}\right)$, tingkat pendidikan $\left(X_{4}\right)$, program pelatihan $\left(X_{5}\right)$ dinyatakan konstan, maka $(X)$ cenderung meningkat. Nilai koefesien $\beta_{1}$ pada variabel independensi bernilai positif maka independensi $\left(X_{1}\right)$ akan cenderung meningkat. Nilai koefesien $\beta_{2}$ pada variabel keahlian professional maka keahlian professional $\left(\mathrm{X}_{2}\right)$ akan cenderung meningkat. Nilai koefesien $\beta_{3}$ pada variabel pengalaman kerja bernilai positif maka pengalaman kerja $\left(X_{3}\right)$ akan cenderung meninggat. Nilai koefesien $\beta_{4}$ pada variabel tingkat pendidikan maka tingkat pendidikan $\left(\mathrm{X}_{4}\right)$ akan cenderung meningkat. Nilai koefesien $\beta_{5}$ pada variabel program pelatihan bernilai positif maka program pelatihan $\left(X_{5}\right)$ akan cenderung meningkat.

Nilai adjusted $R$ Square adalah 0,860 atau $86 \%$, ini berarti sebesar $86 \%$ variasi kinerja dipengaruhi oleh independensi, keahlian professional, pengalaman kerja, tingkat pendidikan dan program pelatihan. Sedangkan sisanya sebesar $14 \%$ dipengaruhi oleh faktor lain yang tidak dimasukkan didalam penelitian ini. Pengujian ini dilakukan untuk mengatahui apakah pengaruh variabel independen yang digunakkan bersifat layak digunakkan atau tidak sebagai variabel penjelas atau predictor. Berdasarkan tabel 8 dapat dilihat bahwa nilai signifikan $\mathrm{F}$ adalah sebesar 0,000 yang lebih kecil dari 5 persen. Hal ini berarti variabel bebas dalam model penelitian ini layak untuk digunakkan.

Hasil pengujian hipotesis untuk variabel independensi menunjukkan nilai signifikan 0,016 kurang dari 0,05 sehingga independensi berpengaruh positif pada kinerja karyawan KSU. Hasil tersebut sejalan dengan hasil penelitian Arysuta, (2011) bahwa independensi secara simultan dan signifikan berpengaruh positif pada kinerja auditor. Hapsari, (2012) juga memperoleh hasil yang sama yakni independensi berpengaruh pada efektivitas pengendalian intern. Independensi memberikan pengaruh kemandirian seorang pengawas untuk melaporkan hasil temuannya kepada pihak pengurus dan rapat anggota tanpa takut dan peduli pada pengaruh yang diberikan oleh orang lain. Independensi membuat pengawas mendapat kepercayaan dari seluruh pihak karena laporan yang diberikan terjamin dan terbebas dari tekanan pihak manapun.

Hasil pengujian variabel keahlian profesional menunjukkan nilai signifikansi 0,016 kurang dari 0,05 sehingga hipotesis dua mengenai pengaruh positif keahlian profesional pada kinerja diterima. Sejalan dengan penelitian Dinata, (2013) bahwa profesionalisme berpengaruh positif pada struktur pengendalian intern. Seorang yang profesional berarti memiliki kemampuan dan ahli dalam bidangnya, memiliki etika profesi, dan ketelitian yang tinggi. Untuk mencapai hal tersebut, seorang pengawas melakukan peningkatan kualitas diri.

Hasil pengujian variabel pengalaman kerja memperoleh nilai signifikansi 0,021 kurang dari 0,05 sehingga hipotesis ketiga diterima. Penelitian Koriah, (2012) juga menunjukkan hasil yang sama, yaitu pengalaman kerja badan pengawas memberikan pengaruh positif pada kinerjanya sehingga meningkatkan efektivitas pengendalian intern. Begitupula penelitian Ariani, (2009) yang menunjukkan bahwa kinerja auditor dipengaruhi secara positif oleh pengalaman kerjanya. Auditor yang berpengalaman mampu menghadapi segala kondisi dan situasi yang terjadi ketika proses pemeriksaan berlangsung, dan memberikan solusi yang lebih beragam atas berbagai kendala yang ditemukan. 
Pengujian variabel tingkat pendidikan menunjukkan nilai signifansi 0,022 kurang dari 0,05, dimana tingkat pendidikan memberikan pengaruh positif pada kinerja. Sama halnya dengan hasil penelitian Ariani, (2009) bahwa tingkat pendidikan auditor berpengaruh positif pada kinerjanya. Pendidikan memberikan pengetahuan dasar mengenai prosedur, dan aturan serta standar yang diberlakukan bagi seorang auditor. Selain itu pendidikan juga memberikan keterampilan yang dibutuhkan dalam melakukan pemeriksaan. Pendidikan yang memadai akan meningkatkan kinerja seorang pengawas.

Pengujian variabel program pelatihan memperoleh nilai signifikansi 0,030 kurang dari 0,05 , sehingga hipotesis lima mengenai pengaruh positif program pelatihan pada kinerja dapat diterima. Program pelatihan dapat meningkatkan keterampilan atau skills para auditor. Pelatihan membantu meningkatkan kemampuan adaptasi dan sosialisasi auditor. Melalui pelatihan, auditor dapat bertemu dengan sesama profesi untuk mendiskusikan berbagai hambatan dan kendala yang dihadapi serta menambah wawasan terkait isu terbaru yang kemungkinan dapat mempengaruhi kinerja mereka. Hasil penelitian ini sejalan dengan Rachmawati, (2011) bahwa pelatihan yang dilakukan berpengaruh positif pada kualitas pengendalian intern.

\section{SIMPULAN}

Kinerja pengawas pada koperasi serba usaha dapat dipengaruhi oleh banyak faktor seperti independensi, keahlian profesional, pengalaman kerja, tingkat pendidikan, dan program pelatihan. Independensi menunjukkan pengaruh positif pada kinerja pengawas. Semakin tinggi independensi yang dimiliki pihak pengawas, maka kinerja akan semakin baik. Independensi merupakan sikap mandiri dan tidak mudah untuk ditekan oleh pihak manapun. Keahlian profesional yang tinggi akan meningkatkan kinerja pengawas. Ahli dan profesional memiliki arti kemampuan dan kecakapan dalam menjalankan tugas sesuai kewajibannya. Semakin banyak pengalaman pengawas maka kinerjanya akan semakin baik. Pendidikan juga tak kalah penting, pendidikan yang tinggi akan meningkatkan kinerja pengawas karena melalui pendidikan pengawas memperoleh banyak ilmu pengetahuan terkait pemeriksaan. Pelatihan merupakan salah satu cara untuk meningkatkan derajat kualitas sumber daya manusia. Pelatihan memberikan bekal keterampilan pada pengawas dan pada akhirnya akan meningkatkan kinerja mereka.

\section{REFERENSI}

Akmal. (2006). Pemeriksaan Intern. Jakarta: PT Indeks Kelompok Gramedia.

Allen. (2005). The Effect of Litigation on Independent Auditor Selection. American Journal of Business.

Ariani. (2009). Pengaruh Profesionalisme, Etika Profesi, Tingkat Pendidikan dan Pengalaman Kerja Inspektorat Provinsi Bali. Universitas Udayana.

Arifin, \& Halomon. (2001). Koperasi Teori dan Praktik. Jakarta: Erlangga.

Bali, S. (2012). Behaviour of Individuals and Institutions in Relation to Finance and Accounting. The Journal of International Social Research, 5(20), 304-314.

Bayu Sadhana, P., \& Rasmini, N. K. (2014). Pengaruh Independensi, Kompetensi, dan Ruang Lingkup Pekerjaan Audit Pengawas Pada Efektivitas 
Pengendalian Intern Koperasi. E-Jurnal Akuntansi Universitas Udayana, 8(3), 371-384.

Bonner, S. (n.d.). Experience Effect in Auditing: The Role of Task-Spesific Knowledge. The Accounting Review, 72-92.

Boyton, \& Kell. (2003). Modern Auditing. Jakarta: Erlangga.

Cloyd, C. . (n.d.). Performance in Reserach Task: The Joint Effect of Knowledge and Accountability. Journal of Accounting Review, 111-132.

Codreanu, A. (2010). Organizational Change: A Matter of Individual and Group Behavior Transformation. Journal of Defense Resource Management, 1(1), 4956. https:// doi.org/10.1016/j.bushor.2012.09.004

Davies, M. (2001). The Changing Face of Internal Audit In Local Goverment. Journal of Finance and Management in Public Service, 1, 79.

Desyanti, N. P. E., \& Ratnadi, N. M. D. (2006). Pengaruh Independensi, Keahlian Profesional, Dan Pengalaman Kerja Pengawas Intern Terhadap Efektivitas Penerapan Struktur Pengendalian Intern Pada Bank Perkreditan Rakyat Di Kabupaten Badung. Jurnal Akuntansi, 3(1), 1-13. https:// doi.org/10.3791/57699

Dianawati, N. M. D., \& Ramantha, W. (2013). Pengaruh Independensi, Keahlian Profesional dan Pengalaman Kerja Auditor Internal terhadap Efektivitas Struktur Pengendalian Internal Bank Perkreditan Rakyat di Kabupaten Gianyar. E-Jurnal Akuntansi Universitas Udayana, 4(3), 439-449.

Dinata, M. (2013). Pengaruh Independensi, Profesionalisme dan Etika Profesi terhadap Kinerja pada Kantor Akuntan Publik di Bali. Universitas Udayana.

Elnaga, A., \& Imran, A. (2013). The Effect of Training on Employee Performance. European Journal of Business an Management, 5(4), 137-147.

Engko, C. (2008). Pengaruh Kepuasan Kerja Terhadap Kinerja Individual Dengan Self Esteem Dan Self Efficacy Sebagai Variabel Intervening. Jurnal Bisnis Dan Akuntansi, 10(1), 1-12.

Fujianti, L. (2012). Pengaruh profesionalisme terhadap komitmen organisasi dan kepuasan kerja serta dampaknya terhadap kinerja akuntan pendidik. Prosiding Seminar Nasional, 816-829.

Górecka, A. S.-, \& Strojek-filus, M. (2017). Behavioral Aspects of Information Created within Accounting System Behavioral Aspects of Information Created within Accounting System. Obuda University E-Bulletin, 7(1), 31-35.

Hakim, A. (2015). Effect of Organizational Culture, Otganizational Comittment to Performance: Study In Hospital Of District South Konawe Of Southeast Sulawesi. The International Journal Of Engineering and Science (IJES), 4(5), 3341.

Halim, A. (2011). Auditing I (Dasar-dasar Audit Laporan Keuangan). Yogyakarta: UPP STIM YKPN.

Hapsari, D. W. (2012). Pengaruh Kompetensi dan Independensi Auditor Internal terhadap Risiko Pengendalian Internal (Studi Kasus Pada Perusahaan Transportasi Darat). Prosiding Seminar Nasional, 785-801.

Hariandja. (2007). Manajemen Sumber Daya Manusia. Jakarta: Grasindo.

Hendrojogi. (2010). Koperasi Asas-asas Teori dan Praktik. Jakarta: Rajawali.

Herliansyah, Y., \& Buana, U. M. (2015). Pengaruh Pengalaman Auditor Terhadap Penggunaan. Buletin Penelitian, (10), 57-68. 
Hery. (2010). Potret Profesi Audit Internal. Bandung: Alfabeta.

Hirth, R. B. (2016). You Are Viewing A Preview Page of the Full ArticleThe article found is from the Gale Academic OneFile. Financial Executive, 4951.

I, D. A. (2011). Pengaruh Independensi, Keahlian Profesional, Pengalaman Kerja, Pendidikan, dan Pelatihan Pengawas Intern terhadap Efektivitas Penerapan Struktur Pengendalian Intern BPR di Kota Denpasar. Universitas Udayana.

Junitayanti. (2011). Pengaruh Independensi, Keahlian Profesional, Tingkat Pendidikan dan Lingkup Pekerjaan pada Kinerja Badan Pengawas sebagai Fungsi Internal Auditor dalam Pengawasan Kredit pada Lembaga Perkreditan Desa Sekecamatan Kuta Badung. Universitas Udayana.

Kalbers, \& Fogarty. (n.d.). Profesionalism and Its Consequences: A Study of Internal Auditor. A Journal of Practice and Theory, 64-84.

Koriah. (2012). Pengaruh Independsi, Keahlian Profesional, dan Pengalaman Kerja Terhadap Efektivitas Penerapan Struktur Pengendalian Intern LPD di Kecamatan Denpasar Selatan. Universitas Udayana.

L, N, A. (2011). Pengaruh Independensi, Kompetensi, dan Kinerja Auditor (Studi pada Auditor BPK RI Perwakilan Provinsi Bali). Universitas Udayana.

Lubis, A. I. (2017). Akuntansi Keperilakuan (3rd ed.). Jakarta: Salemba Empat.

Mangkunegara. (2005). Evaluasi Kinerja SDM. Bandung: PT Refika Aditama.

Mayangsari \& Sekar. (2003). Pengaruh Keahlian Audit dan Independensi terhadap Pendapat Audit: Sebuah Kuasieksperimen. Jurnal Riset Akuntansi Indonesia, 6. No. 1, 1-22.

Mulyadi. (2002). Auditing. Jakarta: Salemba Empat.

Munandar, \& Ashar. (2009). Psikologi Industri dan Organisasi. Jakarta: Universitas Indonesia Press.

Murtanto, \& Gudono. (1999). Indentifikasi Karakteristik-karakteristik Keahlian Audit: Profesi Akuntan Publik di Indonesia. Jurnal Riset Akuntansi Indonesia, 2(Januari), 37-52.

Murtini, N. N. (2017). Pengaruh Independensi, Keahlian Profesional, Pengalaman Kerja, dan Tingkat Pendidikan pada Kinerja Pengawas Koperasi di Kecamatan Rendang Kabupaten Karangasem. Universitas Udayana.

Prawitasari, P. P., Dewa, I., Badera, N., Kunci, K., Pengawas, :, Kinerja, I., \& Profesional, K. (2015). Pengaruh Independensi, Keahlian Profesional, Dan Pengalaman Kerja Pada Kinerja Pengawas Koperasi Serba Usaha. Jurnal Akuntansi Universitas Udayana, 111, 2302-8556.

Putra, I. G. A. D., \& Wisadha, I. G. S. (2013). Pengaruh Profesionalisme, Independensi, Dan Pengalaman Auditor Pada Kualitas Audit Badan Pengawas Lembaga Perkreditan Desa (LPD). Jurnal Ilmiah Akuntansi Dan Bisnis, 8(2), 89-98.

R, A. (1984). Auditor Independence. Journal of Accounting Reserach, 22(1).

Rachmawati. (2011). Pengaruh Independensi, Keahlian Profesional, Pengalaman Kerja, dan Program Pelatihan terhadap Kualitas Pengendalian Intern: (Studi Kasus pada Direktorat Jendral Hak Kekayaan Intelektual Kementrian Hukum dan Hak Asasi Manusia). Universitas Negeri Islam.

Rahma. (2012). Pengaruh profesionalisme, Etika Profesi, Tingkat Pendidikan, Independensi Auditor, Pengalaman Kerja, dan Budaya Kerja Auditor Terhadap Kinerja Auditor pada Kantor Akuntan Publik di Bali. Universitas Udayana. 
Rai. (2008). Audit Kinerja pada Sektor Publik. Jakarta: Salemba Empat.

Salusu. (2008). Pengambilan Keputusan Strategik: untuk Organisasi Publik dan Organisasi Non Profit. Jakarta: PT Grasindo.

Sawyer's. (n.d.). Internal Auditing. Jakarta: Salemba Empat.

Sukrisno. (2004). Auditing (Pemeriksaan Akuntan). Jakarta: Lembaga Penerbit Fakultas Ekonomi dan Bisnis Udayana.

Syafaruddin. (2001). Manajemen Sumber Daya Manusia. Yogyakarta: Badan Penerbit Fakultas Ekonomi.

Trisnaningsih, S. (2007). Independensi auditor dan komitmen organisasi sebagai mediasi pengaruh pemahaman. Simposium Nasional Akuntansi X, 1-56. https://doi.org/10.1590/S0104-14282003000200006

Yasa, G. W., \& Saputra, I. G. W. (2013). Pengaruh Independensi, Profesionalisme, Tingkat Pendidikan, dan Pengalaman Kerja pada Kinerja Auditor BPK RI Perwakilan Provinsi Bali. E-Journal Akuntansi Universitas Udayana, 2(2).

Zhang, Y., Zhou, J., \& Zhou, N. (2007). Audit committee quality, auditor independence, and internal control weaknesses. Journal of Accounting and Public Policy, 26(3),

https://doi.org/10.1016/j.jaccpubpol.2007.03.001 